https://doi.org/10.5800/GT-2017-8-3-0251

\title{
CO-EVOLUTION OF PROTEROZOIC CRATONIC FRAGMENTS IN WESTERN AND NORTHERN MONGOLIA
}

\author{
Uyanga Bold1, Francis Macdonald², Yukio Isozaki1 \\ ${ }^{1}$ Department of Earth Science and Astronomy, University of Tokyo, Meguro-ku, Tokyo 153-8902, Japan \\ 2 Earth and Planetary Sciences Department, Harvard University, Cambridge, MA 02138, \\ United States of America
}

For citation: Bold U., Macdonald F., Isozaki Y., 2017. Co-evolution of Proterozoic cratonic fragments in Western and Northern Mongolia. Geodynamics \& Tectonophysics 8 (3), 417-420. doi:10.5800/GT-2017-8-3-0251.

CAOB occupies a vast area that extends from the Urals to the Far East Asia and from the Siberian craton to the North China and Tarim cratons (Fig. 1, $A$ ). In order to better constrain Precambrian tectonic evolution of the $\mathrm{CAOB}$, it is important to revisit Precambrian terranes of Mongolia as outlined in Badarch et al. [2002] that contain Archean to Proterozoic metamorphic basement and Neoproterozoic metasedimentary and volcanic rocks.

The Zavkhan terrane (Fig. 1, B) is located in the southwestern part of Mongolia and it is well known for its rich exposures and preservation of Precambrian rocks (for example [Bold et al., 2013; Bold et al., 2016b; Macdonald et al., 2009; Smith et al., 2015]). The TuvaMongolia zone ([Dergunov, 2001]; referred to as the Khubsugul Terrane in Macdonald and Jones [2011]) is located directly north of the Zavkhan terrane and comprised of Agardag, Sangelin, Hug, Darhad, and Gargan terranes [Badarch et al., 2002]. Boundary is defined by $\sim 375 \mathrm{~km}$ long, left-lateral strike slip fault, Bulnay Fault [Rizza et al., 2015].

Methods. Neoproterozoic siliciclastic units of the Darkhad and Khuvsgul groups of the Tuva-Mongolia zone were sampled for U-Pb zircon geochronology 


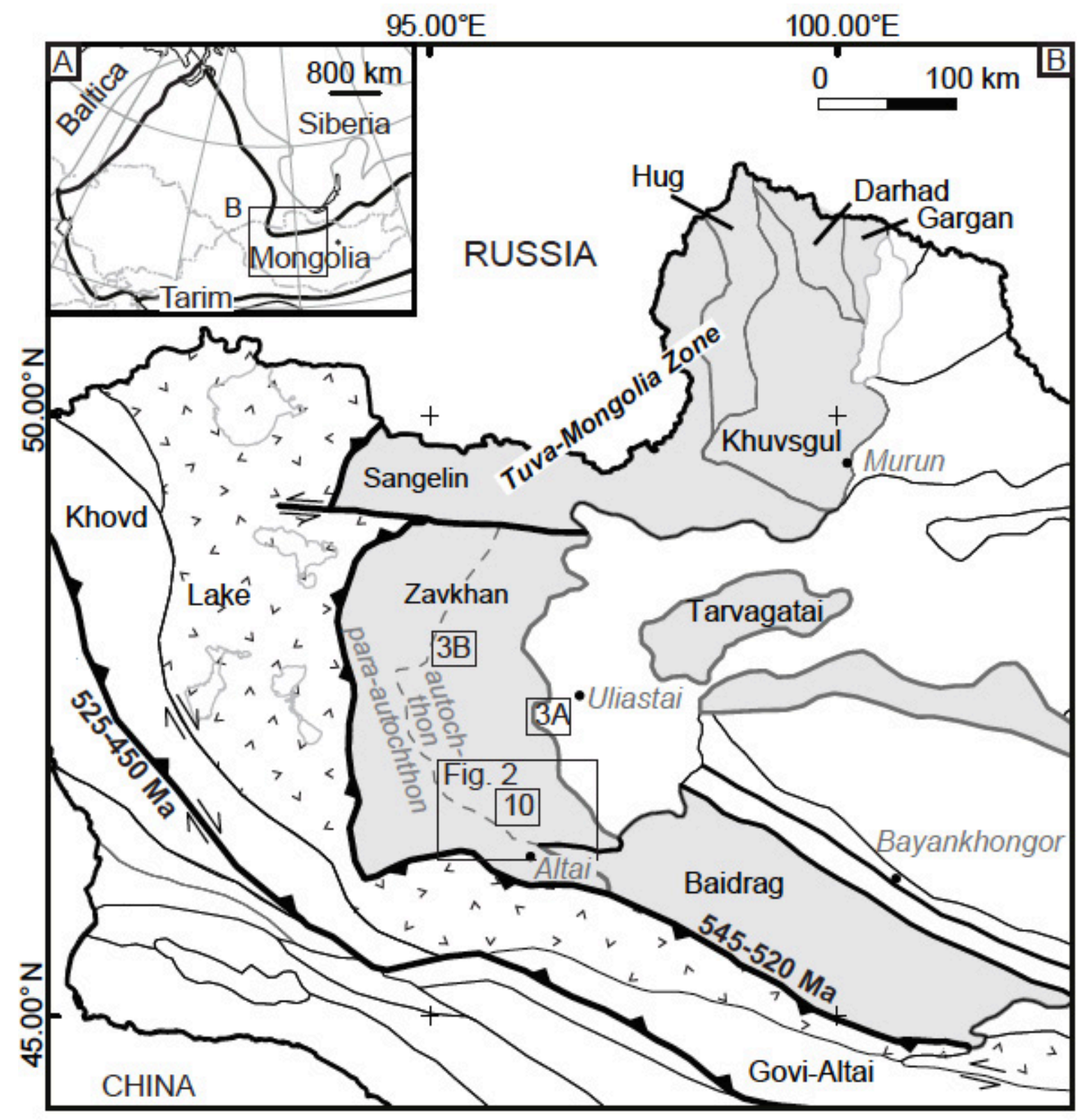

Fig. 1. $A$ - Simplified map of the Central Asian orogenic belt; $B$ - Simplified terrane map of Mongolia [Bold et al., 2016a]. Proterozoic cratonic fragments are grey.

during a geologic mapping work in 2013. Using standard techniques, zircon grains were separated at the Department of Earth Sciences and Astronomy of the University of Tokyo and were analyzed by laser ablation inductively coupled plasma mass spectrometry (LA-ICMPS) at the Gakushuin University of Japan.

Discussion. Detrital zircon studies have been minimally incorporated into origination questions of the Proterozoic cratonic fragments of Mongolia except what is discussed in Salnikova et al. [2001] from metasediments of the Tuva-Mongolia zone, Bold et al. [2016a] from the Zavkhan terrane, and Rojas-Agramonte et al. [2011]. Detrital zircon spectra of the Neoproterozoic siliciclastic rocks of the Zavkhan terrane yielded prominent age peaks at 2600-2400, 2100-1950, and 950-700 Ma [Bold et al., 2016a]. Detrital zircon spectra of the same age siliciclastic rocks of the Tuva-Mongolia zone also yielded major age peaks at 2100-1950 and 950-700 Ma (Fig. 2).

These detrital zircon spectra suggest that TuvaMongolia zone and Zavkhan terrane may have coevolved in the Precambrian and are most similar to detrital zircon data from Tarim. This data suggest that the bounding Bulnay fault is not as old as suggested in (modified from [Bold et al., 2016a]) and that the Precambrian terranes in Mongolia all may be exotic to Siberia. Furthermore, orogenesis began around these cratonal fragments, which were later trapped between 


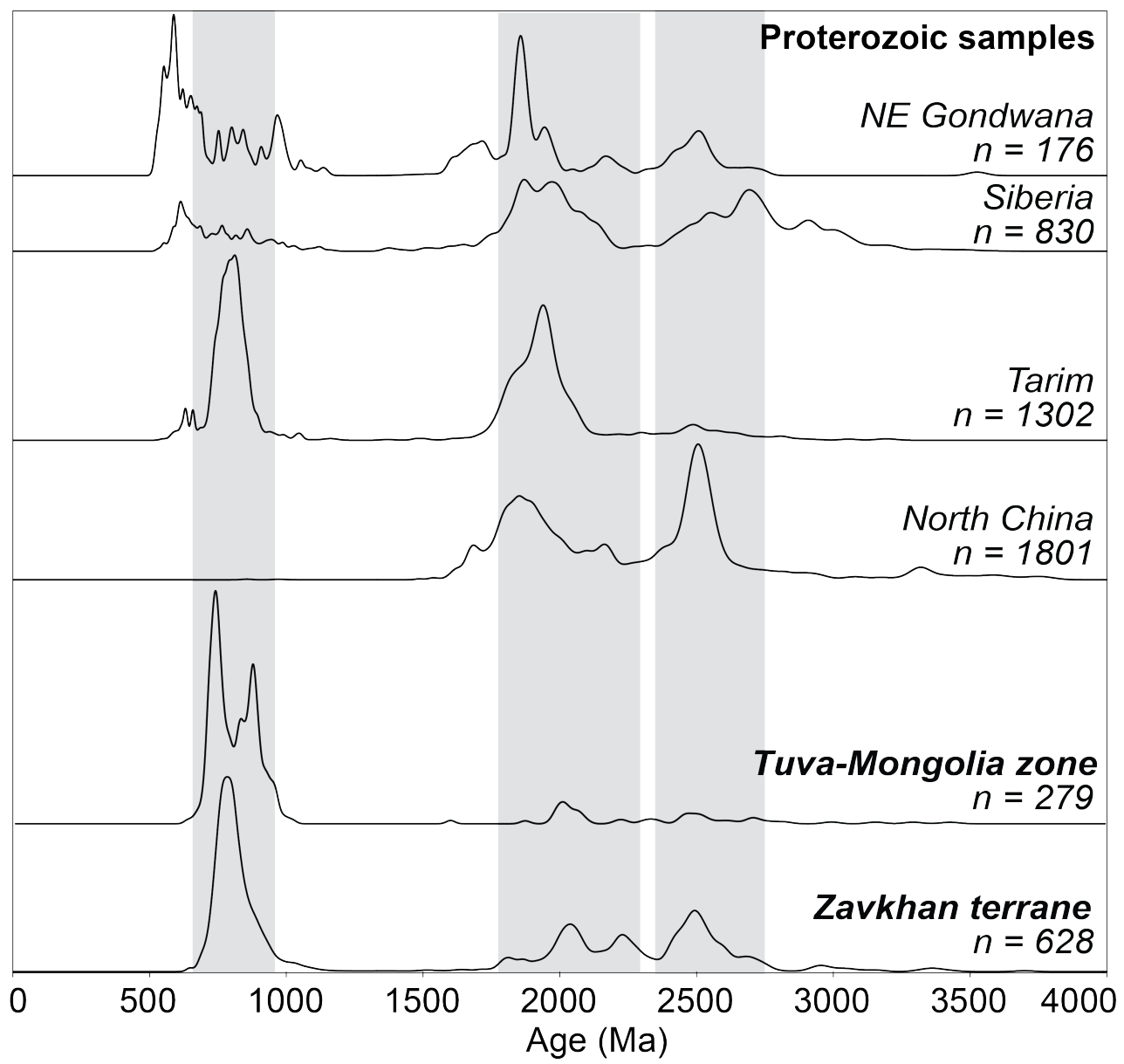

Fig. 2. Detrital zircon provenance of the Zavkhan terrane and Tuva-Mongolia zone. Note the comparison with the neighboring stable cratons (modified from [Bold et al., 2016a]).

larger cratons to form the CAOB. These data also highlight the need for more geochronologic data from Neo- proterozoic strata deposited on the southern margin of the Siberian craton.

\section{REFERENCES}

Badarch G., Cunningham W.D., Windley B., 2002. A new terrane subdivision for Mongolia: implications for the Phanerozoic crustal growth of Central Asia. Journal of Asian Earth Sciences 21 (1), 87-110. https://doi.org/10.1016/ S1367-9120(02)00017-2.

Bold U., Crowley J.L., Smith E.F., Sambuu O., Macdonald F.A., 2016a. Neoproterozoic to early Paleozoic tectonic evolution of the Zavkhan terrane of Mongolia: Implications for crustal growth in the Central Asian Orogenic Belt. Lithosphere 8 (6), 729-750. https://doi.org/10.1130/L549.1.

Bold U., Macdonald F.A., Smith E.F., Crowly J.C., Minjin C., Dorjnamjaa D., 2013. Elevating the Neoproterozoic TsagaanOlom Formation to a Group. Mongolian Geoscientist 39 (5), 89-94.

Bold U., Smith E.F., Rooney A.D., Buchwaldt R., Ramezani J., Schrag D.P., Macdonald F.A., 2016b. Neoproterozoic stratigraphy of the Zavkhan terrane of Mongolia: The backbone for Cryogenian and Early Ediacaran chemistratigraphic records. American Journal of Science 316 (1), 1-63. https://doi.org/10.2475/01.2016.01.

Dergunov A.B., 2001. Tectonics, Magmatism, and Metallogeny of Mongolia. Psychology Press, Hove, UK, 288 p.

Macdonald F.A., Jones D.S., 2011. The Khubsugul Group, northern Mongolia. In: E. Arnaud, G.P. Halverson, G. ShieldsZhou (Eds.), The geological record of Neoproterozoic glaciations. Geological Society, London, Memoirs, vol. 36, p. 339-345. https://doi.org/10.1144/M36.30.

Macdonald F.A., Jones D.S., Schrag D.P., 2009. Stratigraphic and tectonic implications of a newly discovered glacial diamictite - cap carbonate couplet in southwestern Mongolia. Geology 37 (2), 123-126. https://doi.org/10.1130/ G24797A.1. 


\section{U. Bold et al.: Co-evolution of Proterozoic cratonic fragments in Western and Northern Mongolia}

Rizza M., Ritz J.F., Prentice C., Vassallo R., Braucher R., Larroque C., Arzhannikova A., Arzhannikov S., Mahan S., Massault M., 2015. Earthquake geology of the Bulnay fault (Mongolia). Bulletin of the Seismological Society of America 105 (1), 72-93. https://doi.org/10.1785/0120140119.

Rojas-Agramonte Y., Kröner A., Demoux A., Xia X., Wang W., Donskaya T., Liu D., Sun M., 2011. Detrital and xenocrystic zircon ages from Neoproterozoic to Palaeozoic arc terranes of Mongolia: significance for the origin of crustal fragments in the Central Asian Orogenic Belt. Gondwana Research 19 (3), 751-763. https://doi.org/10.1016/j.gr. 2010.10 .004

Salnikova E., Kozakov I., Kotov A., Kröner A., Todt W., Bibikova E., Nutman A., Yakovleva S., Kovach V., 2001. Age of Palaeozoic granites and metamorphism in the Tuvino-Mongolian massif of the Central Asian mobile belt: loss of a Precambrian microcontinent. Precambrian Research 110 (1-4), 143-164. https://doi.org/10.1016/S0301-9268 (01)00185-1.

Smith E.F., Macdonald F.A., Petach T.A., Bold U., Schrag D.P., 2015. Integrated stratigraphic, geochemical, and paleontological late Ediacaran to early Cambrian records from southwestern Mongolia. Geological Society of America Bulletin 128 (3-4), 442-468. https://doi.org/10.1130/B31248.1. 